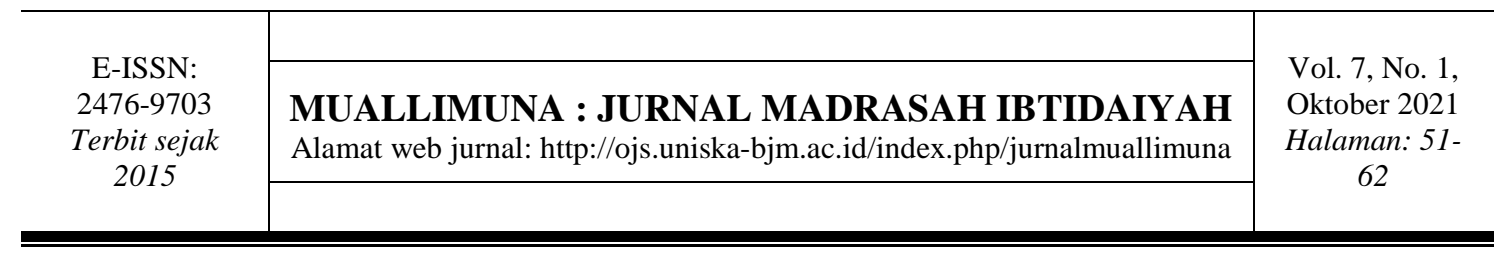

\title{
PENGARUH MODEL PROBLEM BASED LEARNING (PBL) PADA PEMBELAJARAN MATEMATIKA SISWA SEKOLAH DASAR: STUDI META-ANALISIS
}

\author{
Fatkhul Arifin ${ }^{1}$, Tri Anzani Ashari ${ }^{2}$, Fauzan $^{3}$ \\ 1,2,3 Pendidikan Guru Madrasah Ibtidaiyah, UIN Syarif Hidayatullah Jakarta \\ ${ }^{1}$ fatkhul_arf@uinjkt.ac.id, ${ }^{2}$ anzani.ashari15@mhs.uinjkt.ac.id, ${ }^{3}$ fauzan@uinjkt.ac.id
}

\begin{abstract}
Abstrak: Penelitian ini bertujuan untuk mengetahui besar pengaruh model Problem Based Learning (PBL) pada pembelajaran Matematika secara keseluruhan dan berdasarkan variabel terikat pada beberapa jurnal ilmiah di jenjang pendidikan dasar pada jenjang pendidikan dasar. Metode yang digunakan adalah meta-analisis yaitu review naratif dekriptif atau review sistematik dengan menganalisis hasil-hasil penelitian yang telah dipublikasikan secara nasional yang berkaitan dengan pengaruh model Problem Based Learning (PBL) pada pembelajaran Matematika siswa sekolah dasar. Sampel dalam penelitian ini berupa teknik random sampling dengan jumlah tiga belas artikel jurnal yang telah dipublikasikan secara nasional di Indonesia dengan rentang tahun 2014-2020 pada jenjang pendidikan dasar yang membahas penulisan eksperimen mengenai pengaruh model Problem Based Learning (PBL) dalam pembelajaran Matematika siswa sekolah dasar. Instrumen yang digunakan yaitu berupa lembar pemberian kode (coding data) yang merangkum data dan informasi jurnal. Berdasarkan analisis nilai pengaruh secara keseluruhan didapatkan nilai rata-rata besar pengaruh sebesar 0,416 yang berarti dalam kategori efek besar. Temuan analisis juga menunjukkan bahwa model pembelajaran problem based learning memberikan pengaruh pada pembelajaran Matematika jenjang pendidikan dasar. Hal ini menunjukkan kesimpulan bahwa model pembelajaran problem based learning lebih efektif digunakan dalam pembelajaran Matematika dibandingkan dengan model pembelajaran konvensional dalam studi ini.
\end{abstract}

Kata Kunci: meta-analisis, problem based learning, effect size, hasil belajar matematika.

\section{THE EFFECT OF PROBLEM BASED LEARNING (PBL) MODEL ON MATHEMATICS LEARNING OF ELEMENTARY SCHOOL : META-ANALYSIS STUDY}

\begin{abstract}
This study aims to determine the influence of the Problem Based Learning $(P B L)$ learning model on the overall mathematics learning in several scientific journals at the basic education level "at the basic education level. The method used is metaanalysis, namely a descriptive narrative review or systematic review by analyzing the results. The results of research that have been published nationally relating to the influence of the Problem Based Learning (PBL) learning model on elementary school students' mathematics learning The sample in this study is a random sampling technique with a total of thirteen journal articles that have been published nationally in Indonesia
\end{abstract}


with a span of years. 2014-2020 at the basic education level which discusses the writing of experiments on the effect of the Problem Based Learning (PBL) learning model in elementary school students' Mathematics learning. The instrument used is a coding data sheet that summarizes the data. and journal information. Based on the analysis of the overall effect value, the average value of the influence is 0.416 , which means that it is in the large effect category. The findings of the analysis also show that the problem-based learning model has an influence on Mathematics learning in basic education. This shows the conclusion that the-pl problem based learning model is more effective in learning mathematics compared to the conventional learning model in this study.

\section{Keywords: meta-analysis, problem based learning, effect size, mathematics learning outcomes}

\section{PENDAHULUAN}

Pendidikan merupakan salah satu hal yang penting untuk pembangunan suatu bangsa. Pendidikan senantiasa menjadi hal utama yang harus diperhatikan untuk memajukan suatu generasi demi generasi yang sejalan dengan kemajuan masyarakatnya. Menurut Zaenal Arifin, pendidikan juga merupakan suatu usaha yang dilakukan untuk mengembangkan kemampuan dan kepribadian individu melalui proses atau kegiatan tertentu (pengajaran, bimbingan, atau latihan) serta interaksi antara individu dengan lingkungannya(Arifin, 2011). Sangat wajar jika kemajuan suatu bangsa bisa dilihat dari seberapa besar perhatian bangsa tersebut terhadap pendidikan.

Matematika adalah salah satu komponen dari serangkaian mata pelajaran yang mempunyai peranan penting bagi pendidikan. Matematika merupakan salah satu bidang studi yang mendukung perkembangan ilmu pengetahuan dan teknologi. Mata pelajaran matematika selalu identik dengan angka dan rumus sehingga membuat gairah belajar siswa kurang (Kaharuddin et al., 2020). Menurut Ali Hamzah matematika adalah ilmu deduktif yang tidak menerima generalisasi yang didasarkan pada hasil observasi (induktif) tetapi diterima generalisasi yang didasarkan kepada pembuktian secara deduktif. (Hamzah \& Muhlisrarini, 2014). Dalam kehidupan sehari-hari Matematika berfungsi juga untuk melatih ketelitian, kecermatan serta untuk memecahkan suatu masalah. Salah satu tujuan belajar matematika bagi siswa/mahasiswa adalah agar ia mempunyai kemampuan atau ketrampilan dalam memecahkan masalah atau soal-soal matematika, sebagai sarana baginya untuk mengasah penalaran yang cermat, logis, kritis, dan kreatif (Widjajanti, 2009). Keberhasilan pemahaman siswa terhadap pembelajaran Matematika dapat dilihat dari hasil belajar yang telah mereka dapatkan. Pada umumnya di sekolah dasar menunjukkan bahwa pembelajaran matematika diberikan secara klasikal melalui ceramah tanpa melihat kemungkinan penerapan model lain sesuai dengan materi yang akan diajarkan sehingga mengakibatkan peserta didik kurang aktif dalam mengikuti pelajaran yang disampaikan guru, peserta didik juga tidak tertarik mengikuti pelajaran, dan tidak adanya kesadaran akan pentingnya pelajaran matematika. Sehingga mengakibatkan peserta didik tidak memahami pelajaran dan akhirnya bergantung pada guru dan teman-teman mereka. Hal ini menyebabkan kegiatan pembelajaran kurang memberikan makna bagi siswa. Sehingga materi yang dipelajari tidak bertahan lama dalam ingatan siswa serta hanya berupa hapalan tanpa ada pemahaman dan pengaplikasian.

Salah satu model pembelajaran yang dapat meningkatkan pemahaman dan hasil belajar siswa adalah model Problem Based Learning. Kemendikbud tahun 2013 
menyatakan bahwa pembelajaran berbasis masalah (Problem Based Learning) merupakan sebuah pendekatan pembelajaran yang menyajikan masalah kontekstual sehingga merangsang peserta didik untuk belajar. PBL (Pembelajaran berbasis masalah) adalah salah satu pendekatan pembelajaran yang dirancang untuk membantu peserta didik mengembangkan keterampilan berpikir, keterampilan memecahkan masalah, dan keterampilan intelektualnya (Sulistyani, 2018)(Ikman et al., 2016). Menurut Toharudin, berpendapat bahwa model pembelajaran Problem Based Learning (PBL) adalah suatu pembelajaran atau pelatihan yang memiliki karakteristik penggunaan masalah sebagai konteks individu atau seseorang dalam mempelajari keterampilan berpikir kritis dan pemecahan masalah serta memperoleh pengetahuan (Toharudin et al., 2011)(Faqiroh, 2020). Melalui pembelajaran Problem Based Learning, siswa belajar dihadapkan pada permasalahan yang didasarkan pada pengalaman nyata. Pada model ini guru berfungsi sebagai fasilitator serta mediator bagi siswa. Menurut M. Taufiq Amir Problem Based Learning adalah metode pendidikan yang mendorong siswa untuk mengenal cara belajar dan bekerja sama dalam kelompok untuk mencari penyelesaian masalah-masalah di dunia nyata (Amir, 2016). Pembelajaran Problem Based Learning dilakukan mulai dari guru memberi masalah yang berkaitan dengan dunia nyata, peserta didik kemudian secara aktif mengidentifikasi masalah dengan pengetahuan mereka, mengaitkan materi dengan masalah, dan pada akhirnya membuat kesimpulan serta solusi dari masalah yang telah diberikan. PBL mempersiapkan peserta didik berpikir kritis, analitis, dan menemukan dengan menggunakan berbagai macam sumber (Herzon et al., 2018). Proses pembelajaran dengan Problem Based Learning dapat membuat peserta aktif selama proses pembelajaran. Selain itu, pembelajaran berbasis masalah sangat berkaitan dengan realitas kehidupan nyata peserta didik sehingga peserta didik belajar tidak hanya pada wilayah pengetahuan, tetapi juga mengalami dan merasakan.

Kurikulum 2013 menganut pandangan dasar bahwa pengetahuan tidak dapat dipindahkan begitu saja dari guru ke peserta didik. Proses pembelajaran bukan model banking atau transfer of knowledge semata, melainkan merupakan pemberian stimulan kepada peserta didik supaya mampu berpikir kritis dan menjadi problem solver. Peserta didik adalah subyek yang memiliki kemampuan untuk secara aktif mencari, mengolah, mengkonstruksi, dan menggunakan pengetahuan.(Majid, 2014) Maka model pembelajaran Problem Based Learning memiliki kesesuaian dengan orientasi pusat pembelajaran adalah peserta didik.

Berdasarkan uraian di atas peneliti akan mengambil beberapa penelitian yang memiliki satu topik atau tema yang sama dalam penelitian ini dengan menggunakan metode meta-analisis. Menurut Rusman, meta analisis adalah suatu teknik statistika untuk menggambarkan hasil dua atau lebih penelitian sejenis sehingga diperoleh paduan data secara kuantitatif (Rusman, 2014). Metode ini digunakan untuk meringkas, merangkum dan memperoleh intisari hasil temuan dari sejumlah penelitian. Menurut Kadir, meta-analisis dapat bersifat kuantitatif dan merupakan suatu analisis statistik untuk memperoleh serangkaian informasi yang berasal dari sejumlah data dari penelitian-penelitian sebelumnya (Kadir, 2017b).

Terdapat beberapa penelitian meta-analisis, seperti yang telah dilakukan oleh Indri Anugraheni memaparkan hasil meta-analisis model pembelajaran Problem Based Learning (PBL) dalam meningkatkan keterampilan berpikir kritis di Sekolah Dasar terhadap 23 artikel penelitian bahwa model tersebut mampu meningkatkan kemampuan berpikir peserta didik mulai dari yang terendah $2.87 \%$ sampai yang tertinggi $33.56 \%$ dengan rata-rata $12.73 \%$ (Anugraheni, 2018). Selanjutnya penelitian yang dilakukan 
oleh Yenti Wintaria Tumangkeng pada tahun 2018 tentang meta analisis pengaruh media pembelajaran terhadap hasil belajar matematika siswa. Penelitian tersebut mengitung effect size dari tiga puluh satu penelitian skripsi mahasiswa pendidikan matematika. Dari penelitian tersebut didapatkan rata-rata sebesar 0.95. hal ini menunjukkan bahwa penggunaan media dapat meningkatkan hasil belajar matematika siswa sebesar $43.82 \%$ (Tumangkeng et al., 2018). Sedangkan pada studi lain, Kadir mengungkapkan tentang meta-analisis pada efektivitas penerapan pendekatan problem based learning dalam pembelajaran sains dan matematika bahwa memiliki pengaruh yang besar dengan harga besar pengaruh 1.079 (Kadir, 2017a). Beberapa penelitian meta-analisis yang telah dilakukan tersebut secara keseluruhan belum fokus pada pembelajaran Matematika, belum ada penelitian meta-analisis terbaru mengenai penggunaan model pembelajaran Problem Based Lerning (PBL) dengan fokus pelajaran Matematika tingkat Sekolah Dasar di Indonesia.

Berdasarkan dari uraian diatas, dapat diketahui bahwa pengetahuan seseorang dapat diserap dengan baik jika menggunakan model pembelajaran yang menarik dan tidak membosankan, maka tujuan dari penelitian ini yaitu untuk mengetahui besar pengaruh model pembelajaran Problem Based Learning (PBL) pada pembelajaran Matematika secara keseluruhan dan berdasarkan variabel terikat pada beberapa jurnal ilmiah di jenjang pendidikan dasar.

\section{METODE}

Metode penelitian yang digunakan adalah meta-analisis yaitu review naratif deskriptif atau review sistematik dengan menganalisis hasil-hasil penelitian yang telah dipublikasikan secara nasional yang berkaitan dengan pengaruh model pembelajaran Problem Based Learning (PBL) pada pembelajaran Matematika siswa sekolah dasar. Menurut Syamsul, penelitian meta analisis disebut juga disebut penelitian meta atau meta research. Penelitian ini menggunakan pustaka, buku ataupun jurnal sebagai sumber datanya (Hadi, 2006)(Putri et al., 2019). Penelitian meta-analisis ini menggunakan sampel tiga belas artikel jurnal relevan yang telah dipublikasikan secara nasional di Indonesia rentang tahun 2014-2020 pada jenjang pendidikan dasar. Berikut identitas penelitian yang kami jadikan objek penelitian:

Tabel 1. Metode Penelitian

\begin{tabular}{|c|c|c|c|}
\hline No & Author & Judul & Metode Penelitian \\
\hline 1 & $\begin{array}{l}\text { Fransiskus } \\
\text { Timu, Melkoir } \\
\text { Wewe, Maria } \\
\text { I.K Meo Nau } \\
\text { nsiskus Timu, } \\
\text { Melkoir } \\
\text { Wewe, Maria } \\
\text { I.K Meo Nau }\end{array}$ & $\begin{array}{l}\text { Pengaruh Model } \\
\text { Problem Based } \\
\text { Learning } \\
\text { Terhadap Hasil } \\
\text { Belajar } \\
\text { Matematika } \\
\text { Siswa SD }\end{array}$ & $\begin{array}{l}\text { Metode penelitian yang digunakan pada } \\
\text { penelitian ini merupakan Quasi Eksperimen } \\
\text { (eksperimen semu) dengan rancangan } \\
\text { penelitian yang digunakan adalah Non } \\
\text { Equivalent Control Group Pretest-Posttes } \\
\text { Design. Populasi dalam penelitian ini adalah } \\
\text { seluruh siswa kelas IV SDK Ngedukelu } \\
\text { yang berjumlah } 45 \text { siswa. Pengambilan } \\
\text { kelas menggunakan teknik random } \\
\text { sampling yakni dengan pengundian kelas } \\
\text { Sampel yang digunakan terdiri dari } 2 \text { kelas } \\
\text { yakni kelas IV A berjumlah } 22 \text { siswa } \\
\text { sebagai kelas eksperimen, dan kelas IV B } \\
\text { berjumlah } 23 \text { peserta didik sebagai kelas } \\
\text { kontrol. }\end{array}$ \\
\hline
\end{tabular}




\begin{tabular}{|c|c|c|c|}
\hline 2 & $\begin{array}{l}\text { Frienda } \\
\text { Wimadwi } \\
\text { Permastya, K. } \\
\text { Y. Margiati, } \\
\text { Nurhadi }\end{array}$ & $\begin{array}{lc}\text { Pengaruh } & \text { Model } \\
\text { Problem } & \text { Based } \\
\text { Learning } & \\
\text { Terhadap } & \text { Hasil } \\
\text { Belajar } & \text { Siswa } \\
\text { Dalam } & \\
\text { Pembelajaran } \\
\text { Matematika } \\
\text { Kelas V } \\
\end{array}$ & $\begin{array}{l}\text { Metode yang digunakan dalam penelitian } \\
\text { ini adalah Eksperimen dengan bentuk } \\
\text { penelitian Quasi Eksperimen Design dengan } \\
\text { rancangan penelitian nonequivalent control } \\
\text { group design. Sampel pada penelitian ini } \\
\text { adalah siswa kelas VA yang berjumlah } 20 \\
\text { orang dan kelas VB yang berjumlah } 20 \\
\text { orang. }\end{array}$ \\
\hline 3 & $\begin{array}{l}\text { Ni Kadek Putri } \\
\text { Maharani, A.A } \\
\text { Gede Agung, } \\
\text { Ndara Tanggu } \\
\text { Renda }\end{array}$ & $\begin{array}{l}\text { Pengaruh Model } \\
\text { Pembelajaran } \\
\text { BerbasihMasalah } \\
\text { Berbantuan LKS } \\
\text { Terhadap Hasil } \\
\text { Belajar } \\
\text { Matematika } \\
\text { Ssiswa Kelas V }\end{array}$ & $\begin{array}{l}\text { Metode penelitian yang digunakan pada } \\
\text { penelitian ini adalah kuasi eksperimen } \\
\text { dengan rancangan Non-equivalen post test } \\
\text { only control group design. Populasi } \\
\text { penelitian adalah siswa kelas V SD di } \\
\text { Gugus X Kecematan Buleleng berjumlah } 75 \\
\text { siswa. Sampel penelitian adalah siswa kelas } \\
\text { V SDN } 1 \text { Kaliuntu berjumlah } 28 \text { orang dan } \\
\text { siswa kelas V SDN } 3 \text { Kaliuntu berjumlah } 32 \\
\text { orang, ditentukan dengan teknik random } \\
\text { sampling jenis cluster sampling. }\end{array}$ \\
\hline 4 & $\begin{array}{l}\text { Komang Putri } \\
\text { Padmayani, I } \\
\text { Wayan Wiarta, } \\
\text { Made Putra }\end{array}$ & $\begin{array}{lr}\text { Pengaruh } & \text { Model } \\
\text { Problem } & \text { Based } \\
\text { Learning } & \\
\text { Berbantuan } \\
\text { Tutor } & \text { Sebaya } \\
\text { Terhadap } & \text { Hasil } \\
\text { Belajar } & \text { Siswa } \\
\text { Kelas V } & \end{array}$ & $\begin{array}{l}\text { Penelitian ini merupakan penelitian } \\
\text { eksperimen dengan desain eksperimen } \\
\text { semu, yaitu Nonequivalent control group } \\
\text { design. Populasi dalam penelitian ini adalah } \\
\text { siswa kelas V di Gugus I Mengwi tahun } \\
\text { pelajaran 2016/2017. Sampel penelitian ini } \\
\text { ditentukan menggunakan simple random } \\
\text { sampling. Kelas VA di SD No. } 2 \text { Cemagi } \\
\text { terpilih sebagai kelompok eksperimen dan } \\
\text { kelas VA di SD No. } 4 \text { Cemagi terpilih } \\
\text { sebagai kelompok kontrol dalam penelitian } \\
\text { ini. }\end{array}$ \\
\hline 5 & $\begin{array}{lr}\text { Teguh Adi } \\
\text { Saputra, Nurul } \\
\text { Kemala Dewi, } \\
\text { Siti Istiningsih }\end{array}$ & $\begin{array}{ll}\begin{array}{l}\text { Pengaruh } \\
\text { Problem }\end{array} & \text { Model } \\
\text { Learning } & \\
\text { Terhadap } & \text { Hasil } \\
\text { Belajar } & \\
\text { Matematika } \\
\text { Siswa Kelas IV } \\
\text { SDN 1 Kawo } \\
\text { Tahun } & \text { Ajran } \\
\text { 2019/2020 } & \\
\end{array}$ & $\begin{array}{l}\text { Metode penelitian yang digunakan adalah } \\
\text { penelitian eksperimen dengan Quasi } \\
\text { Experimental Design bentuk Nonequivalent } \\
\text { Control Group Design. Populasi dalam } \\
\text { penelitian ini adalah siswa kelas IV SDN } 1 \\
\text { Kawo. Dengan jumlah smpel sebanyak } 36 \\
\text { siswa yang terbagi menjadi dua kelas yakni } \\
\text { kelas IV A } 18 \text { siswa dan IV B } 18 \text { siswa. }\end{array}$ \\
\hline 6 & $\begin{array}{l}\text { Putu Agus Eka } \\
\text { Mastika Yasa, } \\
\text { Wilibaldus } \\
\text { Bhoke }\end{array}$ & $\begin{array}{lc}\text { Pengaruh } & \text { Model } \\
\text { Problem } & \text { Based } \\
\text { Learning } & \\
\text { Terhadap } & \text { Hasil } \\
\text { Belajar } & \\
\text { Matematika } & \end{array}$ & $\begin{array}{l}\text { Metode penelitian yang digunakan pada } \\
\text { penelitian ini ialah quasi eksperimen dengan } \\
\text { rancangan penelitian yang digunakan adalah } \\
\text { non equivalent kontrol group design. } \\
\text { Populasi penelitian ini ialah seluruh siswa } \\
\text { kelas V Gugus II Kecamatan Jerebuu yang }\end{array}$ \\
\hline
\end{tabular}




\begin{tabular}{|c|c|c|c|}
\hline & & Pada Siswa SD & $\begin{array}{l}\text { berjumlah } 29 \text { siswa. Sampel penelitian ini } \\
\text { adalah siswa kelas V SDN Bena sebagai } \\
\text { kelas eksperimen yang berjumlah } 15 \text { orang } \\
\text { dan kelas V SDI Kolokoa sebagai kelas } \\
\text { kontrol yang berjumlah } 14 \text { orang. }\end{array}$ \\
\hline 7 & $\begin{array}{l}\text { Sartika } \\
\text { Dwimaya }\end{array}$ & $\begin{array}{l}\text { Pengaruh Model } \\
\text { Problem Based } \\
\text { Learning } \\
\text { Terhadap Hasil } \\
\text { Belajar } \\
\text { Matematika } \\
\text { Pada Siswa SD }\end{array}$ & $\begin{array}{l}\text { Metode yang digunakan dalam penelitian } \\
\text { ini adalah Eksperimen dengan bentuk } \\
\text { penelitian Quasi Eksperimen Design dengan } \\
\text { rancangan penelitian nonequivalent control } \\
\text { group design. Populasi dalam penelitian ini } \\
\text { adalah seluruh siswa kelas III SD Negeri } \\
\text { Nogopuro sebanyak } 54 \text { siswa. Sampel pada } \\
\text { penelitian ini adalah siswa kelas III A yang } \\
\text { berjumlah } 27 \text { orang dan kelas II B yang } \\
\text { berjumlah } 27 \text { orang. }\end{array}$ \\
\hline 8 & $\begin{array}{l}\text { I Md. Arta, I } \\
\text { G. N. Japa, I } \\
\text { K. Sudarma }\end{array}$ & $\begin{array}{l}\text { Problem Based } \\
\text { Learning } \\
\text { Berbantuan } \\
\text { Icebreaker } \\
\text { Berpengaruh } \\
\text { Terhadap } \\
\text { Kemampuan } \\
\text { Pemecahan } \\
\text { Masalah } \\
\text { Matematika }\end{array}$ & $\begin{array}{l}\text { Metode yang digunakan pada penelitian } \\
\text { yang dilaksanakan merupakan penelitian } \\
\text { eksperimen semu dengan rancangan } \\
\text { penelitian post-test only group design. } \\
\text { Populasi penelitian ini adalah siswa kelas } \\
\text { IV SD yang berjumlah } 179 \text { siswa. Sampel } \\
\text { penelitian ini diambil dengan teknik random } \\
\text { sampling dan hasilnya } 53 \text { siswa sebagai } \\
\text { sampel. }\end{array}$ \\
\hline 9 & $\begin{array}{l}\text { Dwi Setyo } \\
\text { Rini, } \\
\text { Wsitohadi }\end{array}$ & $\begin{array}{l}\text { Pengaruh Model } \\
\text { Pembelajaran } \\
\text { Problem Based } \\
\text { Learning } \\
\text { Terhadap } \\
\text { Kemampuan } \\
\text { Pemecahan } \\
\text { Masalah } \\
\text { Matematika } \\
\text { Peserta Didik } \\
\text { Kelas V SD }\end{array}$ & $\begin{array}{l}\text { Metode yang digunakan pada penelitian ini } \\
\text { adalah eksperimen semu. Populasi dalam } \\
\text { penelitian ini yaitu siswa SDN Ledok, } \\
\text { Salatiga. Sampel pada penelitian ini adalah } \\
\text { siswa kelas V SDN Ledok } 02 \text { Salatiga yang } \\
\text { berjumlah } 29 \text { siswa dan SDN Ledok } 07 \\
\text { Salatiga yang berjumlah } 38 \text { siswa. }\end{array}$ \\
\hline 10 & $\begin{array}{l}\text { Yudi } \quad \text { Cahyo } \\
\text { Winoto, Tego } \\
\text { Prasetyo }\end{array}$ & $\begin{array}{l}\text { Efektivitas } \\
\text { Model Problem } \\
\text { Based Learning } \\
\text { Terhadap } \\
\text { Kemampuan } \\
\text { Berpikir Kritis } \\
\text { Siswa Sekolah } \\
\text { Dasar }\end{array}$ & $\begin{array}{l}\text { Metode penelitian yang digunakan pada } \\
\text { penelitian ini merupakan Quasi Eksperimen } \\
\text { (eksperimen semu). Sampel pada penelitian } \\
\text { ini adalah SDN Tlogo sejumlah } 29 \text { siswa } \\
\text { sebagai kelas eksperimen dan SDN Tretep } \\
\text { sejumlah } 30 \text { siswa sebagai kelas control. }\end{array}$ \\
\hline 11 & $\begin{array}{l}\text { Elva Pristy } \\
\text { Afifah, } \\
\text { Wahyudi, } \\
\text { Yohana }\end{array}$ & $\begin{array}{l}\text { Efektivitas } \\
\text { Problem Based } \\
\text { Learning } \\
\text { Terhadap }\end{array}$ & $\begin{array}{l}\text { Metode yang digunakan pada penelitian ini } \\
\text { adalah eksperimen menggunakan metode } \\
\text { eksperimen kuasi dengan pola non- } \\
\text { equivalent control group design. Sampel }\end{array}$ \\
\hline
\end{tabular}




\begin{tabular}{|c|c|c|c|}
\hline & Setiawan & $\begin{array}{l}\text { Kemampuan } \\
\text { Berpikir Kritis } \\
\text { Ssiswa Kwelas } \\
\text { V Dalam } \\
\text { Pembelajaran } \\
\text { Matematika }\end{array}$ & $\begin{array}{l}\text { pada penelitian ini yaitu } 23 \text { siswa SDN } \\
\text { Gedangdowo } 02 \text { dan } 18 \text { siswa SDN Soko }\end{array}$ \\
\hline 12 & $\begin{array}{l}\text { Arnoldus } \\
\text { Helmon }\end{array}$ & $\begin{array}{l}\text { Pengaruh } \text { Model } \\
\text { Problem Based } \\
\text { Learning (PBL) } \\
\text { Terhadap } \\
\text { Kemampuan } \\
\text { Berpikir Kritis } \\
\text { Siswa SD }\end{array}$ & $\begin{array}{l}\text { Metode penelitian pada penelitian ini } \\
\text { merupakan quasi experiment dengan } \\
\text { menggunakan Nonequivalent groups } \\
\text { pretest-posttest control group design. } \\
\text { Populasinya adalah siswa kelas IV SDN } \\
\text { Serayu, Kota Yogyakarta. Sampelnya } \\
\text { adalah adalah kelas IV A dan IV B }\end{array}$ \\
\hline 13 & $\begin{array}{l}\text { Lovika Ardana } \\
\text { Riswari, Diana } \\
\text { Ermawati }\end{array}$ & $\begin{array}{l}\text { Pengaruh } \\
\text { Problem Based } \\
\text { Learning } \\
\text { Dengan Metode } \\
\text { Demonstrasi } \\
\text { Terhadap } \\
\text { Kemampuan } \\
\text { Pemecahan } \\
\text { Masalah } \\
\text { Matematika }\end{array}$ & $\begin{array}{l}\text { Metode penelitian pada enelitian ini adalah } \\
\text { quasy experimental dengan desain } \\
\text { pretestposttest control grup design yang } \\
\text { menggunakan dua kelas sebagai kelompok } \\
\text { eksperimen dan kelompok kontrol. } \\
\text { Populasi dalam penelitian ini adalah siswa } \\
\text { kelas IV SD Se-gugus Diponegoro } \\
\text { Kecamatan Kota, Kabupaten Kudus. } \\
\text { Sampel diperoleh dari dua SD yang berbeda } \\
\text { yang dipilih menggunakan teknik purposive } \\
\text { sampling yaitu SD } 1 \text { Kajeksan dan SD } 2 \\
\text { Demaan dengan masing-masing-masing } 30 \\
\text { siswa }\end{array}$ \\
\hline
\end{tabular}

Instrumen yang digunakan dalam penelitian ini adalah lembaran pemberian kode (coding data). Adapun variabel yang digunakan untuk pemberian kode dalam menjaring informasi mengenai besar pengaruh (effect size) pada penelitian meta-analisis sebagaimana yang telah dilakukan oleh Kadir, yaitu (Kadir, 2017c):

1. Data artikel yang terdiri dari nama peneliti, judul penelitian, nama jurnal dan tahun publikasi;

2. Karakteristik sampel berupa tempat penelitian, subjek penelitian dan sampel penelitian;

3. Variabel, desain dan instrument berupa variabel independen dan dependen, desain penelitian dan pengujian hipotesis;

4. Intervensi pembelajaran kelas eksperimen dan kelas kontrol;

5. Effect size; dan (6) rerata effect size.

Rumus yang digunakan dalam penelitian ini adalah rumus formula effect size yang digunakan yaitu formula eta square $\left(\square^{2}\right)$. Penelitian eksperimen yang hanya melibatkan dua kelompok, yaitu kelompok kelompok eksperimen dan kelompok kontrol, menggunakan analisis komperasi dengan teknik analisis uji-t, maka menggunakan formula effect size sebagai berikut (Kadir, 2017b):

Keterangan :

$$
\eta^{2}=\frac{J K_{\text {antara }}}{J K_{\text {total }}}
$$


$\mathrm{r}^{2} \quad=$ Koefisien determinasi

$\mathrm{t}_{\mathrm{o}}^{2}=\mathrm{t}_{\text {hitung }}$

$\mathrm{db}=$ Derajat Bebas

Kriteria yang digunakan untuk membantu interpretasi hasil effect size menggunakan acuan dari Gravetter dan Wallnu, yaitu:

Efek kecil $: 0.01<\eta^{2} \leq 0.09$

Efek sedang : $0.09<\eta^{2} \leq 0.25$

Efek besar : $0.09<\Sigma \eta^{2}>0.25$

\section{HASIL DAN PEMBAHASAN \\ Hasil}

Pada penelitian ini jumlah artikel yang digunakan yaitu tiga belas artikel yang sesuai dengan kriteria yang telah ditentukan dan dalam rentang tahun 2014-2020. Adapun data hasil analisis pengelompokan effect size secara keselurhan berdasarkan kategori dan berdasrarkan variabel terikat.

Data Hasil Pengelompokan Effect Size Secara Keseluruhan Berdasarkan Kategori Hasil analisis dari artikel-artikel yang tercantum dalam koding data dihitung nilai effect size-nya, kemudian dikelompokkan berdasarkan kategori yang terdiri dari tiga kriteria yaitu efek kecil $\left(0.01 \square \square \square \square^{2} \leq 0.09\right)$, efek sedang $\left(0.09 \square \square \square^{2} \leq 0.25\right)$ dan efek besar $\left(0.09 \square \square \square \square^{2}>0.25\right)$ dapat dilihat pada Tabel 1 berikut:

Tabel 2. Effect Size Berdasarkan Kategori

\begin{tabular}{|c|c|c|c|c|c|}
\hline No. & $\begin{array}{c}\text { Kode } \\
\text { Artikel } \\
\end{array}$ & Effect Size & $\begin{array}{c}\text { Rerata } \\
\text { Effect Size }\end{array}$ & Kategori & $\begin{array}{c}\mathbf{N} \\
\text { Artikel } \\
\end{array}$ \\
\hline 1 & A11 & 0.100 & 0.100 & Efek Sedang & \multirow{6}{*}{6} \\
\hline 2 & A2 & 0.136 & 0.136 & Efek Sedang & \\
\hline 3 & A7 & 0.141 & 0.141 & Efek Sedang & \\
\hline 4 & A5 & 0.157 & 0.157 & Efek Sedang & \\
\hline 5 & A9 & 0,196 & 0,196 & Efek Sedang & \\
\hline 6 & A13 & 0,197 & 0,197 & Efek Sedang & \\
\hline 7 & A8 & 0.252 & 0.252 & Efek Besar & \multirow{7}{*}{7} \\
\hline 8 & $\mathrm{~A} 4$ & 0.330 & 0.330 & Efek Besar & \\
\hline 9 & A12 & 0,462 & 0,462 & Efek Besar & \\
\hline 10 & A6 & 0.534 & 0.534 & Efek Besar & \\
\hline 11 & A3 & 0.948 & 0.948 & Efek Besar & \\
\hline 12 & A1 & 0.968 & 0,968 & Efek Besar & \\
\hline 13 & A10 & 0.989 & 0.989 & Efek Besar & \\
\hline \multicolumn{3}{|c|}{$\begin{array}{c}\text { Rerata Effect Size Berdasarkan } \\
\text { Kategori }\end{array}$} & 0.416 & Efek Besar & 13 \\
\hline
\end{tabular}

Hasil data analisis pada tabel 4.2 menunjukkan bahwa terdapat enam artikel publikasi ilmiah dengan kategori effect size sedang dan tujuh artikel publikasi ilmiah dengan kategori effect size besar. Dari perhitungan yang ada pada tabel, diperoleh rerata effect size berdasarkan kategori yaitu 0.416 dengan kategori effect size besar. Jadi, dapat disimpulkan bahwa effect size dari hasil keseluruhan dengan model pembelajaran 
Problem Based Learning (PBL) pada pelajaran Matematika memiliki pengaruh yang besar.

Data Hasil Pengelompokan Effect Size Berdasarkan Variabel Terikat

Data hasil effect size berdasarkan variabel terikat dalam pembelajaran Problem Based Learning (PBL) pada pelajaran Matematika dapat dilihat pada tabel 4.3 berikut:

Tabel 3. Data Hasil Pengelompokan Effect Size Berdasarkan Variabel Terikat

\begin{tabular}{|c|l|c|c|}
\hline No & \multicolumn{1}{|c|}{ Variabel Terikat } & N Artikel & Rerata Effect Size \\
\hline 1 & Kemampuan Berpikir Kritis & 3 & 0.517 \\
\hline 2 & Hasil Belajar & 7 & 0.412 \\
\hline 3 & Kemampuan Pemecahan Masalah & 3 & 0.215 \\
\hline \multicolumn{2}{r|}{ Mean } & 3 & 0.381 \\
\hline
\end{tabular}

Hasil analisis data pada Tabel 4.3 menunjukkan bahwa rata-rata effect size model pembelajaran Problem Based Learning (PBL) pada variabel terikat dari yang tertinggi ke terendah adalah pertama; kemampuan berpikir kritis yang terdiri dari tiga artikel dengan rerata effect size 0.517, kedua; hasil belajar terdiri dari tujuh artikel dengan rerata effect size 0,412, ketiga; kemampuan pemecahan masalah yang terdiri dari tiga artikel dengan rerata effect size 0,215 . Berdasarkan penjabaran pada tabel 4.3 nilai ratarata dari seluruh varibel terikat adalah 0.381 . Jadi, dapat disimpulkan bahwa variabel terikat dalam pembelajaran dengan model Problem Based Learning (PBL) pada pelajaran Matematika yang memiliki nilai rerata effect size tertinggi adalah variabel kemampuan berpikir kritis.

\section{Pembahasan}

Effect size digunakan untuk menunjukkan besarnya suatu pengaruh dari adanya sebuah perlakuan. Dengan menggunakan effect size maka penelitian dapat dilakukan dengan lebh mudah. Hubungan antar variabel dalam meta-analisis ini adalah antara pengaruh model problem based learning dengan hasil belajar siswa pada pembelajaran Matematika. Berdasarkan dari hasil penelitian dapat dilihat jika model problem based learing (PBL) sangat memberikan pengaruh yang besar dalam meningkatkan hasil belajar siswa pada pembelajaran matematika. Dari 13 artikel terdapat 6 artikel memberikan pengaruh yang besar dan 7 artikel memberikan pengaruh sedang.

Data analisis perhitungan pada tabel 1 menunjukkan bahwa secara keseluruhan rata-rata nilai effect size model pembelajaran problem based learning (PBL) pada pelajaran Matematika sebesar 0.416. angka tersebut bermakna bahwa perlakuan model pembelajaran problem based learning (PBL) pada pembelajaran matematika memberikan pengaruh yang besar terhadap siswa. Temuan ini sejalan dengan Kadir pada penelitian Meta-analisis Intervensi Berpikir Matematika (Mathematical Thinking) dengan harga besaran pengaruh (effect size) 0.155 dalam ketentuan Cohen pada kriteria eta-square $\left(\square \square \square^{2}\right.$ )dengan diperoleh klasifikasi efek tinggi(Kadir, 2017a). Hal tersebut diperkuat dengan penelitian terkait meta analisis terhadap problem based learning (PBL) yang dilakukan oleh Anik dan Henny, pada penelitian tersebut dihasilkan nilai selisih terendah 2,65\% dan tertinggi 19,90 rata-rata sebesar 11,28. Dari nilai tersebut membuktikan bahwa penerapan model PBL berpengaruh terhadap peningkatan berpikir kreatif siswa (Anik Handayani \& Henny Dewi Koeswanti, 2019).

Berdasarkan keseluruhan jurnal yang telah di analisis, terdapat temuan analisis yang menunjukkan bahwa model pembelajaran Problem Based Learning memberikan pengaruh yang besar pada pembelajaran matematika siswa Sekolah Dasar. Hal ini dapat 
dibuktikan dengan adanya hasil penelitian yang dilakukan oleh peneliti terhadap pembelajaran yang dapat membantu siswa untuk meningkatkan hasil belajar, mendorong siswa untuk berpikir kritis dan membantu siswa dalam memecahkan suatu permasalahan saat kegiatan pembelajaran. Hal tersebut menunjukkan bahwa model pembelajaran Problem Based Learning (PBL) memberikan pengaruh yang lebih efektif dan model pembelajaran Problem Based Learning (PBL) merupakan salah satu model pembelajaran yang layak digunakan dalam pembelajaran Matematika siswa.

Hasil tersebut sesuai dengan penelitian yang dilakukan oleh Melek Demirel (2016) dengan judul "effects of problem-based learning on attitude: a metaanalysis study". Temuan penelitian mengenai meta-analisis pengaruh pembelajaran berbasis masalah terhadap sikap menunjukan hasil yang positif dalam hal peningkatan sikap siswa terhadap program dibandingkan dengan pengajaran tradisional, tetapi nilai rata-rata efect size yang dihasilkan rendah yaitu pada angka 0.44. (Demirel \& Dağyar, 2016).

Proses pembelajaran yang dilakukan oleh guru meskipun menggunakan jenis model yang sama, ada kemungkinan penerapannya mengalami perbedaan. Tingkat kemampuan dari masing-masing siswa juga berbeda sehingga hal tersebut dapat mempengaruhi hasil belajar yang diperoleh. Permasalahan yang terjadi pada proses pembelajaran matematika adalah cara guru mengajar yang masih menggunakan metode ceramah dan menjelaskan materi di depan kelas. Permasalahan lain yang dihadapi yaitu keaktifan para peserta didik dalam mengikuti pembelajaran masih dinilai kurang. Permasalahan tersebut terjadi akibat para guru salah dalam memilih model pembelajaran. Dengan menggunakan model problem based learning dapat meningkatkan hasil belajar siswa serta siswa semakin terampil dalam memecahkan suatu masalah. Penerapan model problem based learning ini juga dapat menumbuhkan motivasi para siswa dalam belajar. Keunggulan dari pembelajaran model problem based learning adalah para siswa mendapat manfaat dari proses pembelajaran karena masalah yang dihadapkan kepada anak dikaitkan dengan kehidupan yang nyata, hal ini juga dapat meningkatkan motivasi dan ketertarikan terhadap suatu materi yang sedang dipelajari oleh siswa.

\section{PENUTUP}

Berdasarkan hasil analisis yang telah dilakukan, besar pengaruh model pembelajaran Problem Based Learning terhadap pembelajaran matematika secara keseluruhan yaitu sebesar 0,416 dan berdasarkan variabel terikat yaitu sebesar 0,381. Jadi, model pada pembelajaran matematika secara keseluruhan dan berdasarkan variabel terikat memiliki pengaruh yang besar. Peneliti menyarankan jika melakukan penelitian yang sama terkait meta analisis, diharapkan data yang dipakai jurnal-jurnal penelitian relevan dan terakreditasi tidak kurang dari 5 tahun. Sehingga hasil penelitian yang dimuat tidak terlalu lama. Semakin banyak data yang dihitung, semakin baik effect size yang dihasilkan.

\section{DAFTAR PUSTAKA}

Amir, M. T. (2016). Inovasi Pendidikan Melalui Problem Based Learning Bagaimana Pendidik Memberdayakan Pembelajar di Era Pengetahuan. Kencana Predana Media.

Anik Handayani, \& Henny Dewi Koeswanti. (2019). Meta-Analisis Model Pembelajaran Problem Based Learning (PBL) Untuk Meningkatkan Kemampuan 
Berpikir Kreatif. Jurnal Basicedu, 1(1), 1-9.

Anugraheni, I. (2018). Meta Analisis Model Pembelajaran Problem Based Learning dalam Meningkatkan Keterampilan Berpikir Kritis di Sekolah Dasar. A Journal of Language, Literature, Culture, and Education Polyglot, 14(1), 9-18.

Arifin, Z. (2011). Evaluasi Pembelajaran. Remaja Rosdakarya.

Demirel, M., \& Dağyar, M. (2016). Effects of Problem-Based Learning on Attitude: A Meta-analysis Study. EURASIA Journal of Mathematics, Science and Technology Education, 12(8), 2115-2137. https://doi.org/10.12973/eurasia.2016.1293a

Faqiroh, B. Z. (2020). Problem Based Learning Model for Junior High School in Indonesia (2010-2019). Indonesian Journal of Curriculum and Educational Technology Studies, 8(1), 42-48. https://doi.org/10.15294/ijcets.v8i1.38264

Hadi, S. (2006). Metodologi Penelitian Kuantitatif untuk Akuntasi dan Keuangan. Ekonsia.

Hamzah, M. A., \& Muhlisrarini. (2014). Perencanaan dan Strategi Pembelajaran Matematika. Rajawali Pers.

Herzon, H. H., Budijanto, B., \& Utomo, D. H. (2018). Pengaruh Problem-Based Learning (PBL) terhadap Keterampilan Berpikir Kritis. Jurnal Pendidikan: Teori, Penelitian, Dan Pengembangan, 3(1), 42-46. http://journal.um.ac.id/index.php/jptpp/article/view/10446

Ikman, Hasnawati, \& Rezky, M. F. (2016). Effect of Problem Based Learning (PBL) Models of Critical Thinking Ability Students on the Early Mathematics Ability. International Journal of Education and Research, 4(7), 361-374.

Kadir. (2017a). Meta-Analisis Pengaruh Intervensi Pembelajaran Terhadap Kemampuan Berfikir Matematis pada Penelitian dan Publikasi Dosen-Mahasiswa Program Studi Pendidikan Matematika UIN Syarif Hidayatullah Jakarta. https://puslitpen.uinjkt.ac.id/wp-content/uploads/ABSTRAK-KADIR.pdf

Kadir. (2017b). Statistik Terapan Konsep Contoh dan Analissi Data dengan Program SPSS/Liseral dalam Penelitian. Raja Grafindo Persada.

Kadir, K. (2017c). Meta-Analysis of the Effect of Learning Intervention Toward Mathematical Thinking on Research and Publication of Student. TARBIYA: Journal of Education in Muslim Society, 4(2), 162-175. https://doi.org/10.15408/tjems.v4i2.8010

Kaharuddin, A., Arifin, S., Tulak, T., \& Suyastini, P. A. (2020). Teams Games Tournament (Tgt) Dan Discovery Learning (Dl) Dalam Pembelajaran Matematika Di Sekolah Dasar. Muallimuna: Jurnal Madrasah Ibtidaiyah, 6(1), 1. https://doi.org/10.31602/muallimuna.v6i1.2371

Majid, A. (2014). Implementasi Kurikulum 2013 kajian Teoretis dan Praktis. Interes Media.

Putri, Y. A., Usman, A., \& Cahyati, M. T. (2019). Meta-Analisis Pengaruh penggunaan Model Inquiry Based Learning terhadap Kompetensi Keterampilan Peserta Didik dalam Pembelajaran Fisika. Jurnal Penelitian Pembelajaran Fisika, 5(1), 65-72. http://ejournal.unp.ac.id/index.php/jppf/article/view/107423

Rusman. (2014). Penerapan Pembelajaran Berbasis Masalah. Edutech, 13(2), 211. https://doi.org/10.17509/edutech.v13i2.3102

Sulistyani, N. (2018). Implementation of Problem-Based Learning Model (Pbl) Based on Reflective Pedagogy Approach on Advanced Statistics Learning. International Journal of Indonesian Education and Teaching, 02(01), 11-19. https://doi.org/10.24071/ijiet.2018.020102 
Toharudin, U., Hendrawati, S., \& Rustaman, A. (2011). Membangun Literasi Sains Peserta Didik. Humaniora.

Tumangkeng, Y. W., Yusmin, E., \& Hartoyo, A. (2018). META-ANALISIS PENGARUH MEDIA PEMBELAJARAN TERHADAP HASIL BELAJAR MATEMATIKA SISWA. Computers and Industrial Engineering, 2(January), 6. http://ieeeauthorcenter.ieee.org/wp-content/uploads/IEEE-Reference-

Guide.pdf\%0Ahttp://wwwlib.murdoch.edu.au/find/citation/iee.html\%0Ahttps://do i.org/10.1016/j.cie.2019.07.022\%0Ahttps://github.com/ethereum/wiki/wiki/WhitePaper\%0Ahttps://tore.tuhh.de/hand

Widjajanti, D. B. (2009). KEMAMPUAN PEMECAHAN MASALAH MATEMATIS MAHASISWA CALON GURU MATEMATIKA: APA dan BAGAIMANA MENGEMBANGKANNYA. Jurnal Pendidikan Matematika, 3(2), 402-413. 